(7) I. Mazuruk, 26 May 1937, by aircraft from Franz Josef Land, landing twice on the ice.

(8) V. Molokov, 26 May 1937, by aircraft from Franz Josef Land, landing on the ice.

(9) A. Alekseyev, 28 May 1937, by aircraft from Franz Josef Land, landing twice on the ice.

(10) V. Chkalov, 19 June 1937, by aircraft during his transarctic flight from Moscow to the U.S.A.

(11) M. Gromov, 13 July 1937, by aircraft during his transarctic flight from Moscow to the U.S.A.

(12) S. Levanevski, 13 August 1937, by aircraft during his transarctic flight from Moscow to the U.S.A. The flight was not finished; the plane disappeared without a trace between the Pole and the U.S.A.

(13) M. Vodop'yanov, 7 October 1937, by aircraft from Franz Josef Land during the search for Levaneski.

(14) Ya. Moshkovski, 4 April 1938, by aircraft from Franz Josef Land during the search for Levanevski.

(15) D. C. McKinley, 17 May 1945, by aircraft from Iceland.

(16) M. Titlov, 2 October 1945, by aircraft from Taymyr Peninsula.

(17) United States Army Air Force B-29 aircraft, spring 1946, from Fairbanks, Alaska.

\title{
ISTITUTO GEOGRAFICO POLARE, ITALY
}

A new Polar Institute, the Istituto Geografico Polare, has been formed in Italy under the directorship of Dr Silvio Zavatti. It was founded towards the end of 1944 in Forli, but has since been moved to Macerata.

In the statutes of the Institute (Forli, 1945) it is stated that its aims are:

(1) To promote and encourage exploration that will widen the knowledge of the Polar areas.

(2) To encourage interest in Polar affairs in Italy and to publish Italian contributions to Polar knowledge.

(3) To form a Polar library which will include relevant Italian and foreign periodicals.

(4) To produce a monthly periodical, Il Polo.

(5) To publish works of scientific value on Polar matters and a series of "Polar Classics".

During 1945 a monthly, Bolletino Mensile d'informazione, was published, since it proved impossible to print a larger periodical owing to lack of paper. The first number of $I l$ Polo came out in February 1946.

The present address of the institute is Porto Potenza Picena, Macerata. There are two sub-sections, one at Forli under Capt. Lanzoni Widmer, the other at Turin under Signor Seto Irenco. The secretary and editor of Il Polo is Signor Adriano Offidani. 